\title{
EZLN: LUTA ARMADA E PLURALIDADE POLÍTICA*
}

\author{
Wilson Silva Silvestre Neto \\ Mestrando em Ciências Sociais pela \\ Universidade Estadual de Londrina
}

\section{Resumo}

O presente trabalho apresenta um primeiro contato com o Exército Zapatista de Libertação Nacional do Estado mexicano de Chiapas. Apreende a gênese do Movimento Zapatista, a partir de uma análise de sua formação político-cultural, levandose en consideração as diferenças existentes no interior do grupo. A análise volta-se também para a situação econômica de Chiapas no momento histórico do Levante Zapatista. E ainda. trata da relação do EZLN com a sociedade civil mexicana, à partir das declarações do grupo e de uma discussão teórica desenvolvida acerca do mesmo.

Palaras-chave: movimentos sociais; espaço político; direitos do homen.

objetivo do presente texto é realizar uma primeira leitura acerca do Exército Zapatista de Libertação Nacional (EZLN), atuante no Estado mexicano de Chiapas. A orientação desta leitura tem o objetivo de ajuntar a compreender a gênese, o desenvolvimento, a formação ideológico cultural e a organização do EZLN, bem como destacar a peculiaridade da sua forma de atuação política.

O EZLN apareceu na grande imprensa após o levante armado iniciado na madrugada do dia primeiro de janeiro de 1994, data marcada para a assinatura do Tratado do Livre Comércio da América do Norte (NAFTA).

\footnotetext{
Versão do Trabalho de Conclusão de Curso (monografia) realizado para obtenção do grau de bacharel em Ciências Sociais pela Universidade Estadual de Londrina en dezembro de 2.000, sob orientação do Prf. ${ }^{\circ}$ Dr. Ricardo de Jesus Silveira e, contantdo a Comissão Examinadora com a ilustre presença dos Prof. ${ }^{\circ} \mathrm{s}$ Drs. Pedro Roberto Ferreira e Kimiye Tommasino.
} 
O movimento tem como estopim a alteração constitucional imposta pelos EUA e pelo Canadá como condição para o que o México pudesse fazer parte do NAFTA. Esta alteração elimina os ejidos, que constituem uma forma de posse para uso coletivo da terra. Os ejidos foram conquistados através da Revolução Mexicana em 1910, e teve como principais forças político-militares as tropas lideradas por Pancho Villa, na região norte, e por Emiliano Zapata, no sul do país.

A gênese, desenvolvimento, ideologia e organização do movimento são abordados destacando-se as origens e as relações internas do EZLN. O que se procura mostrar são suas origens sociais, políticas e culturais e a conseqüente forma de sua organização.

Em um segundo momento, pretende-se relatar alguns dados referentes ao aspecto econômico de Chiapas, com a intenção de estabelecer uma visão geral das condições materiais de vida da população insurgente. E ainda, a contextualização econômica e social do Estado no momento histórico do levante zapatista.

O último tópico corresponde à reflexão acerca das relações estabelecidas entre o EZLN e a sociedade civil mexicana, no sentido de investigar a atitude política de um grupo guerrilheiro que busca a instituição de uma sociedade democrática. Destaca-se assim, o contraste da realidade militar de guerrilha com a consciência política no trato da questão da constituição de um espaço político, no qual os direitos podem, e devem, ser constantemente contestados.

É essencialmente importante não esquecer que, refutando a idéia de construir uma explicação definitiva, a pretensão deste trabalho limita-se ao conhecimento de traços da organização, da ideologia e do projeto do Exército Zapatista de Liberação Nacional. Este primeiro contato tem o propósito de levantar questões que contribuam para futuros estudos mais aprofundados sobre o assunto.

\section{A formação do movimento: sobrevivendo na Selva Lacandona}

La Pisadilla, o pesadelo, fica no interior da Selva Lacandona em Chiapas. La Pisadilla é o nome do acampamento onde no mês de novem- 
bro de 1983 um pequeno grupo de homens fundou o Exército Zapatista de Libertação Nacional (EZLN).

"O EZLN têm duas raízes: um grupo político-militar urbano e uma organização indígena. O grupo urbano era pequeno, de orientação marxista-leninista, formado por gente de classe média que viu fechar suas alternativas políticas pelo monopólio do Partido Revolucionário Institucional (PRI). Era uma organização clandestina que procurava crescer com trabalho político, sabendo que um dia iria aderir à luta armada. Como precisava de um lugar para se preparar militarmente, entrou em contato com indígenas de Chiapas que também haviam concluído que se esgotara a via pacífica. De convergência de interesses surgiu o EZLN, em novembro de 1983." (ORTIZ, 1996, p.40)

O grupo ficou na floresta sem receber ajuda dos vilarejos, contava apenas com a presença de dez indígenas, considerados mais politizados. Os suprimentos chegavam da cidade através de uma rede clandestina. À noite quando desciam aos arredores dos vilarejos eram perseguidos. Os indígenas das comunidades pensavam que eram bandidos, ladrões de gado.

Nos primeiros anos a maior preocupação consistia em como sobreviver na montanha. A sobrevivência e integração à montanha seria sua maior arma. Como passavam até meses sem receber provisões foram forçados a adaptar-se à floresta. Viviam da caça e dos frutos que conseguiam coletar. Para se movimentar sem serem vistos abriram uma rede de atalhos no interior da selva.

A estrutura da formação militar foi construída entre os anos de 1983 e 1985, com estudos sobre as guerrilhas latino-americanas e, por mais irônico que possa parecer, nos manuais de guerrilha e contra-insurreição do exército norte-americano.

"Conhecemos a guerrilha nos manuais dos rangers, dos marines, dos seals, de todos os tipos de comando do exército norte-americano e da OTAN. No que diz respeito ao exército regular, utilizamos os manuais de história militar sobre a época da guerra de independência, sobretudo sobre Morelos, e sobre a Revolução, a Divisão do Norte de Villa e o Exército Libertador do Sul de Zapata. (...)" (GENNARI apud LE BOT, 1997). 
A solidão na montanha provoca tensão psicológica, além das dificuldades físicas de sobrevivência. Os primeiros membros EZLN sofreram com o sentimento de inutilidade de seus sacrifícios perante a situação mundial e a realidade político-social mexicana. Vencer parecia algo impossível. Eles nem sequer existiam aos olhos dos agentes do governo e da economia mundial. A lógica ou o pensamento aparentemente mais sensato apontava diretamente para o o fracasso. Mas o absurdo não é mais forte que o sentimento do homem que decide não mais fazer parte de uma sociedade, cuja realidade parece-lhe inconcebível ou inaceitável.

No início o EZLN existia como um movimento de guenilha isolado em Lacandona. Com o tempo surgiu o contato com as comunidades indígenas mais próximas. A miséria e a repressão agravaram-se na região, o que influenciou na aproximação dos indígenas com os zapatistas. Os guerrilheiros foram bem recebidos pelas comunidades pelo fato de terem sido considerados como homens da montanha, onde viveram, $\mathrm{e}$ não como homens da cidade. Perante as comunidades indígenas, os homens que permaneceram tanto tempo nas montanhas receberam um respeito particular devido à simbologia da tradição cultural indígena.

O grupo indígena mais inserido no EZLN começou a colocar em discussão perante as principais lideranças comunitárias a idéia de luta armada. A violência e a repressão exercidas pelos Latifundiários e assistidas pelo Governo acabaram contribuindo no sentido de fazer com que a população assumisse uma postura de autodefesa.

Os indígenas aceitaram a adesão à luta armada, porém sob a condição de obterem armas e treinamento. O grupo político-militar passou a dar instrução militar à população e esta o abastecia vendendo-lhe bacias, utensílios, arroz, milho, feijão e o que precisassem. Iniciou-se, então, o intercâmbio político, cultural e militar.

As "famílias" tzeltal, tzotzil, chol e tojolabal - etnias de origem maia que aderiram à idéia da guerrilha - convencidas pelo grupo de mediações indígena, começaram a enviar seus filhos jovens para a montanha com o intuito de fazer deles guerrilheiros. Neste momento os indígenas começaram a constituir a maioria de contingentes no interior do EZLN. De tal forma que os indivíduos do grupo político-militar de origem urbana foram obrigados a aprender a língua e a simbologia das comunidades. 
Os indígenas que realizaram a intermediação entre os dois grupos assimilaram o conhecimento político e cultural da organização de guerrilha e o interpretaram segundo as concepções de mundo de suas comunidades, criando algo novo. Esta fusão de culturas distintas fora, por sua vez, repassada aos guerrilheiros indígenas que, sendo maioria no grupo, levaram para as comunidades uma ideologia que já não era mais a concepção inicial do grupo urbano do EZLN, nem tampouco a noção puramente indígena acumulada ao longo de cinco séculos de resistência, desde a apropriação espanhola do território mexicano. Tratava-se de algo novo, que os zapatistas jamais planejaram e de que só tiveram consciência em suas reflexões posteriores. Esta aproximação e esta transformação ocorreram por volta de 1985.

"É uma espécie de tradução, enriquecida pela perspectiva de uma transição política. A idéia de um mundo mais justo, mais ou menos tudo aquilo ao qual anseia o socialismo só que repensado, enriquecido de elementos humanitários, éticos, morais, mais do que propriamente indígenas. A revolução torna-se um problema essencialmente moral. Ético. Mais do que um problema de distribuição de riqueza ou de expropriação de meios de produção, a revolução representa a possibilidade de um espaço de dignidade para o ser humano. A dignidade começa a tornar-se um conceito muito importante e a idéia não é nossa, não vem do grupo urbano, vem das comunidades. A revolução torna-se a garantia de que a dignidade existe e deve ser respeitada." (GENNARI apud LE BOT, 1997).

O produto deste contato entre a organização político-militar e as comunidades indígenas não foi entendido na ocasião de forma consciente pelos integrantes do EZLN. “(...) o EZLN não se dá conta desta tradução, desta gestação fecunda. Não havíamos previsto e nem a entendíamos, achávamos que o EZLN se desenvolveria porque a luz tinha chegado a iluminar a escuridão (...)”. (GENNARI apud LE BOT, 1997).

Os guerrilheiros do EZLN pensavam ter encontrado um povo explorado e precisavam mostrar-lhe o caminho, organiza-lo. O contato

' um ancião profundo conhecedor da cultura do grupo indígena, diversas vezes mencionado como tal nas mensagens do Subcomandante Marcos. 
com as lideranças políticas do grupo de mediação das comunidades indígenas e com o chamado Velho Antônio', fez com que o grupo urbano compreendesse melhor a consciência e tradição histórica de lutas políticas dessas populações. Dessa forma, o grupo urbano assume uma atitude de reforço armado no processo de união com as comunidades rurais indígenas.

Entre 1985 e 1987, os integrantes do grupo urbano do EZLN acreditavam que qualquer pessoa entenderia a linguagem da revolução. Porém, depararam-se com um universo social desconhecido, a cujos problemas suas verdades não seriam capazes de para responder. "A organização político-militar que, digamos permanece ainda na tradição marxista-leninista, de repente descobre a existência de uma realidade que não consegue explicar, da qual não pode prestar contas e junto a qual deve trabalhar." (GENARI, 2000, p.11-12)

O EZLN assume uma postura de aprender com as comunidades, adequando-se a elas e tornando-se mais um aliado às formas de resistência indígena. Se o Capitão Cook, da obra Ilhas de História (SAHLINS,1990), tivesse a mesma preocupação em conhecer a cultura com a qual se relacionava, provavelmente não teria o triste fim de ser sacrificado sem ao menos entender a razão de sua morte e a mudança tão drástica da receptividade dos nativos.

Para Marshal Sahlins (1990) a história é construída culturalmente e a cultura historicamente, de diferentes formas nas diversas sociedades, sistematizadas na ação dos agentes envolvidos. Processo esse resultante da existência e interação das convenções coletivas e atitudes individuais criativas do cotidiano na estrutura, na ordem cultural, por meio do qual se consegue Conseguindo assim, identificar e esclarecer os papéis onde atuam os atores das diversas categorias sociais e se transforma e reafirma o sistema simbólico dentro de uma ordem lógica que tem como referência uma estrutura dada no decorrer da história. Sahlins insiste que para a condição do presente ser fiel ao passado e, ainda assim, transpor-se para ele, é necessário que ela seja determinada pela ordem cultural e pela ação prática dos indivíduos nas diversas situações cotidianas.

A relação dos guerrilheiros com as comunidades ampliou-se entre o final do ano de 1988 e início de 1989 . Os "soldados" permaneciam nas 
montanhas, descendo apenas à noite, quando necessário. No entanto as populações começaram a subir para participar das festas comemorativas de datas históricas mexicanas promovidas pelo EZLN. Neste período já havia centenas de indígenas em treinamento.

As fraudes eleitorais de 1988 representavam, para o segmento indígena mais politizado, o fim da solução pacífica para os problemas de sobrevivência nas comunidades. As epidemias que matavam as crianças na selva e a queda no preço do café também contribuíram para o desdobramento acelerado da guerrilha.

Nessa mesma época, outro fato que contribuiu, para o crédito ao EZLN foi o fracasso do Exército Federal Mexicano ao vasculhar a Selva Lacandona. Oficialmente o que foi dito é que a operação objetivava encontrar supostas plantações de maconha. Acabaram engolidos pela montanha sem encontrar nada - nem maconha, nem guemilheiros - a floresta permaneceu intacta. Isto abalou a credibilidade do exército e com ela a legitimidade do governo instituído.

“(...) podemos afirmar que nenhuma revolução é sequer possível onde a autoridade do corpo político é verdadeiramente intacta, e isso significa, nas condições modernas, onde existe a confiança de que as forças armadas obedecem às autoridades civis. As revoluções sempre parecem alcançar êxito com incrível facilidade em seu estágio inicial, e a razão é que os homens que as fazem só conseguem tomar o poder num regime em plena desintegração; elas são a consequiências e nunca a causa da decadência da autoridade política." (ARENDT, 1991, p.92-93)

Parece certo que a tomada do poder não é o objetivo dos Zapatistas, mas isso não era conhecido e também não é o tema deste artigo. O fato é que a "autoridade do corpo político" corria risco com o desprestígio da incapacidade do controle militar. A resposta foram assassinatos de camponeses nas regiões da Selva Lacandona e do norte de Chiapas. As populações dessas comunidades sentiram que estavam sendo atacadas diretamente pelas forças militares que deveriam protegêlas. Os habitantes das comunidades próximas de Lacandona, consequientemente, não encontravam mais segurança nas vias pacíficas de atuação política. Tal realidade social agredia a dignidade do povo indígena ao ponto de não mais ser possível suportá-la. 
A alteração realizada pelo presidente Carlos Salinas de Gortari no Artigo 27 da Constituição Mexicana transformou os ejidos - forma de propriedade de uso coletivo da terra - em objeto passível de troca comercial, podendo ser comprados e vendidos. Esta alteração levou os camponeses indígenas ejidatários da condição de pobreza à miséria absoluta. Este fato, como veremos no próximo capítulo, caracterizou a exclusão social dos indígenas, deixando-lhes apenas a alternativa da luta armada.

De 1989 a 1990, o EZLN teve seu contingente ampliado de poucas centenas a milhares de combatentes e começou a receber ajuda de diversos povoados da região. Os guerrilheiros andavam abertamente pelos vales da selva, mesmo durante o dia. Transformaram-se então em exército popular que produzia as condições para a guerra e também trabalhavam junto às comunidades, inclusive no cultivo da terra. Foram criadas oficinas para produção de armas; treinaram enfermeiros e professores que ensinassem a ler a história do México, enfim. criou-se um sistema de produção que girava em torno de uma economia de guerra.

"Em 1992, grandes festas oficiais celebraram o quinto centenário da descoberta da América. Não havíamos entendido ainda até a que ponto a conquista fosse importante e carregada de sentido para as comunidades indígenas. No interior do movimento indígena, a nível local e, sem dúvida, também nacional, se produz uma espécie de ebulição, uma necessidade de se expressar que logo de início nós não conseguimos entender. Decidem que deve se comemorar o quinto centenário lembrando a realidade deles: cinco séculos de resistência contra a dominação. O processo de radicalização se acelera, os povoados alcançam o ponto do qual já não dá mais pra voltar: a vontade deles é expressa pelas lideranças indígenas, as lideranças das comunidades e as regionais, que, em seguida, viriam integrar o comitê. As lideranças indígenas declaram que é necessário começar a guerra em 1992. De conum acordo com o comando (eu era o chefe militar), os dirigentes explicam aquilo que já foi dito: que a situação internacional é desfavorável, que a conjuntura nacional não deixa espaço para a menor tentativa de mudança e, menos ainda, para a luta armada. Decidimos juntos que era preciso consultar as comunidades. Esta foi a primeira vez; em seguida, a consulta torna-se uma maneira costumeira de trabalhar nos povoados." (GENNARI, 2000, p.22) 
Nos meses de setembro a novembro de 1992 foi realizada a primeira consulta com cerca de quatrocentas a quinhentas comunidades de quatro etnias: tzotzil, chol, tojolabal e tzelzal. A maioria vota pela guerra.

"Em dezembro de 92, uma vez conhecido o resultado da consulta, fizemos uma reunião entre a direção indígena e o comando "de montanha" do EZLN, durante a qual refletíamos sobre como modificar a estrutura da direção diante da guerra: é necessário que o verdadeiro EZLN, ou seja, as comunidades indígenas, assuma o controle de toda a organização, inclusive nas cidades, e, como queremos que a guerra tenha caráter nacional e não local, ela deve atingir todo o território ou, pelo menos, todos os estados nos quais o EZLN está presente. (GENNARI, 2000, p.22) Formalmente, no final de 92 , era sempre a organização político-militar a ter o comando do EZLN, mas, na realidade, ele já era delegado aos dirigentes das comunidades, aquele que, na época, chamávamos de responsáveis de zona pelas três regiões e responsáveis de etnias pelos quatro grupos étnicos." (GENNARI, 2000, p.15-16).

O movimento zapatista, como ficou conhecido, possui sua peculiaridade que começa pela formação de contingentes, e pela mistura de indígenas com revolucionários urbanos, uns e outros reprimidos pelo sistema político mexicano que entende que apenas um partido político pode estar no poder, o Partido Revolucionário Institucional (PRI).

"O que é novo e autêntico é a interação dialética entre, por um lado, as tradições locais de solidariedade dentro das comunidades e as autoridades locais comprometidas com seu povo e, por outro lado, os revolucionários marxistas, comprometidos com a criação de um movimento revolucionário com a visão de uma sociedade alternativa, sendo ambas partes capazes de aprender com uma experiência prática e adaptar-se a ela." (PETRAS; VIEUX, 1998, p.58)

Em janeiro de 1993 uma nova reunião reafirma a determinação pela guerra. Os representantes indígenas assumem oficialmente o comando do EZLN. Os representantes das etnias e zonas constituem o Comitê Clandestino Revolucionário Indígena, visando garantir que as decisões sejam tomadas com a participação de todas as comunidades indígenas, através de assembléias. 
As lideranças das quatro principais etnias de Chiapas, em assembléias, decidiram pela guerra estabelecendo reivindicações que não eram apenas indígenas, mas abrangiam também interesses de caráter nacional; as palavras de ordem, ainda hoje, são: "Democracia, Liberdade e Justiça". Estas palavras estão presentes em todos os comunicados do EZLN, demonstrando a forte unidade e determinação do grupo desde o início do movimento até os dias atuais.

A pluralidade parece ser um traço comum na formação do EZLN, tanto no que diz respeito à formação de contingente, quanto no que se refere à ideologia e atitude política do movimento. Esta pluralidade está presente no âmbito de cada grupo, não apenas nas diferentes etnias indígenas, mas também no grupo urbano, mesmo antes de se unirem.

"Tendo nascido de uma série de confluências, acontece também uma confluência de idéias: alguns companheiros optavam pelo marxismo ortodoxo, outros vinham de um marxismo mais perto de Gramsci, 'eurocomunistas`, outros ainda não eram marxistas e sim social-democratas (...).” (GENNARI, 2000, p.16).

A Primeira Declaração da Selva Lacandona sintetiza de alguma forma esta confluência de idéias. Trata-se de uma declaração de guerra contra o sistema de partido de Estado. A Declaração visa a transição para a democracia condicionada na realização de suas necessidades listadas em onze pontos: casa, terra, trabalho, pão, saúde, educação, autonomia, liberdade, justiça, democracia e paz. O apelo é dirigido aos senadores e deputados da União para que assumam o controle da transição. A sociedade civil também é chamada a participar, em todas as áreas em que atua, para a transição do que se idealiza como democracia.

O EZLN revela-se ao mundo com a Primeira Declaração. Não impõe um programa que deva ser aceito por quem quer que seja que não queira estar em oposição a ele. Coloca em discussão suas propostas acerca do sistema social e regime político ao qual toda sociedade está submetida, sem impô-las. Não buscam tomar o poder, apenas querem exercer o direito de confrontar idéias e propostas num novo espaço político, diferente do sistema que chamam de "Partido de Estado."”

O EZLN é composto inicialmente por um grupo político-militar que já não conseguia crer nas vias eleitorais para conquistar sua realiza- 
ção política. A constituição de um "exército de libertação nacional" clandestino no meio de uma selva demonstra a desilusão do grupo iniciador do movimento com relação à sua participação na política do país, à restrição da sua liberdade.

Mas o EZLN que o mundo conheceu em primeiro de janeiro de 1994 não era mais o mesmo grupo que entrou na Selva Lacandona em 1983. O contato com os grupos indígenas, que constituíam uma grande parcela da população camponesa e miserável do estado de Chiapas, provocou profundas modificações no interior do grupo, ampliou seu quadro de contingentes e possibilitou a permanência do grupo urbano por um longo período na selva.

Ainda mais que, da sobrevivência na selva, a construção de uma nova concepção político-cultural dependeu e muito dos camponeses indígenas. Os valores, as tradições e a consciência política das etnias de origem maia, contribuíram para a constituição da base ideológica do movimento. O EZLN formou-se na e da relação entre valores e ideais de indivíduos basicamente divididos em dois grupos, um urbano e um indígena; cada giupo abrigava diferenças próprias e convivia com elas, dentro do grupo urbano já havia posturas e ideologias diferentes, assim como entre o grupo indígena cada etnia já possuía também suas peculiaridades. A pluralidade cultural-político-social está presente desde a formação do Movimento Zapatista.

\section{Chiapas: espaço de conflitos}

\section{Chiapas: um lugar rico onde vivem pobres}

Chiapas é um dos 32 estados do México e possui cerca de 75.634 quilômetros quadrados, Seu território é o oitavo maior do país, agregando 111 municípios. O Estado possui 3,5 milhões de habitantes, dos quais noventa por cento ( $90 \%$ ) são trabalhadores rurais e possuem uma renda tão baixa que mal cobre as despesas de alimentação; cinqüenta e

2 O PRI possui uma ligação muito íntima com o Estado mexicano. Em 1928, por decreto. todos os funcionários públicos passaram a ser filiados ao PRI. 
quatro porcento (54\%) da população em todo o Estado é desnutrida, restringindo-se às regiões das montanhas e selva esta estimativa elevase para $80 \%$. Basicamente, a alimentação da população do campo é composta por café, tortilha e feijão. A miséria causa a morte de um indivíduo a cada trinta e cinco minutos no Estado.

Segundo o subcomandante Marcos, em 1990 dois terços do orçamento do Estado de Chiapas foi destinado para o investimento em energia. "Um terço das moradias de Chiapas não tem energia elétrica, embora o Estado forneça sessenta porcento $(60 \%)$ da eletricidade do México."(FUSER, 1996, p.58).

O Estado possui um generoso lençol de petróleo em seu subsolo. De todas as instalações da indústria extrativa petroquímica Pemex, oitenta e dois por cento (82\%) estão implantados em Chiapas. A Pemex absorve 92 mil barris de petróleo, além dos 1,47 bilhões de metros cúbicos de gás por dia nos municípios de Ocosingo, Pichucalco, Ostuacãn, Reforma e Estación Juarez.

Chiapas possui muitas riquezas, mas seus produtores não ficam com os lucros de seu trabalho, ficam apenas com as despesas. Em 1988 o produtor vendia seu café a 2.500 pesos o quilo; este mesmo café foi exportado pelo preço de 8.000 pesos, tendo como um dos maiores compradores os EUA. O Estado produz trinta e cinco por cento $(35 \%)$ do café mexicano, sendo que cinqüienta e três por cento $(53 \%)$ da produção é destinada à exportação. $\mathrm{O}$ gado é comprado do produtor e vendido aos frigoríficos no mercado interno, pelos chamados coiotes, por um preço dez vezes maior. Chiapas produz cerca de 2.756 toneladas de mel e cera anualmente que são destinadas, em sua totalidade, à exportação para a Europa e os EUA.

Um milhão de indivíduos constituem o povo indígena que é formado basicamente por 300 mil tzeltales, 300 mil tzotziles, 120 mil choles, 90 mil zoques e 70 mil tojolabales, dentre outros. Em 1989, o Estado contava

Texto "Chiapas: o sudeste entre dois ventos, uma tempestade e uma profecia" de autoria do Subcomandante Marcos, datado de meados de 1992. encaminhado a público em janeiro de 1994 através do Departamento de Imprensa e Propaganda do EZLN. Selva Lacandona, México; encontrado no site www. E.ZLN.org entre outros sites e demais veículos da imprensa mexicana e internacional. En português. no texto GENNARI (2000b) 
com 16.058 salas de aula, sendo apenas 1.096 em zonas indígenas. Dos alunos que ingressam na primeira série setenta e dois porcento $(72 \%)$ não concluem o primeiro ano de estudo. Metade das escolas não oferecem nenhum ensino além da terceira série, que chamamos aqui de primária. Metade da população indígena é oficialmente considerada analfabeta.

Longe de uma distribuição equilibrada dos recursos, o que se constata é que a área dos povoados indígena possui bem menos que a décima parte das salas de aulas de Chiapas. A população indígena constitui aproximadamente um terço de toda a população do Estado. As crianças nas comunidades indígenas, que deveriam estar na escola, são forçadas a exercer trabalhos "braçais", como carregar milho ou lenha, para garantir a sobrevivência.

A assistência médica no Estado também não é um retrato de distribuição democrática e imparcial da receita mexicana. Chiapas conta com cinco vezes menos consultórios médicos por habitantes que a média dos demais estados do país; são 0,2 consultórios para cada 1.000 habitantes. O número de leitos hospitalares acompanha, de certa forma, a desproporcionalidade: são 0,3 leitos para cada mil indivíduos, estabelecendo uma perspectiva estatística três vezes inferior que a média dos outros Estados. O número de centros cirúrgicos, médicos e enfermeiras é cinquienta porcento $(50 \%)$ menor que o dos outros Estados.

As desigualdades não existem apenas com relação aos outros estados, existe também no interior do estado. "(...) as melhores terras estão nas mãos de apenas vinte famílias(...).Três milhões de hectares, quase a metade da superfície do Estado, pertencem a seis mil pecuaristas, uma ínfima minoria." (FUSER, 1996, p.58). Os governantes de Chiapas protegem os interesses dos latifundiários e dos grandes comerciantes locais, seus aliados políticos. Em contrapartida exercem enorme pressão sobre três dioceses da Igreja católica do Estado que realizam trabalhos assistindo a população carente.

A resistência maior era da Diocese de San Cristobal, liderada pelo bispo Samuel Ruiz, que foi acusado pelo presidente Salinas de ter dado cobertura para o Movimento Zapatista adiantando o horário da missa das 24 horas para as 23 horas e de conhecer a existência do EZLN antes do levante e não comunicar o governo, porém nada ficou provado; o bispo foi peça fundamental nas negociações de paz entre o Governo Federal e o 
EZLN, porém, foi transferido daquela diocese pelo papa no início deste ano. Nos quatro anos do governo de Patrocínio Gonzáles Garrido, no Estado de Chiapas, o conflito entre latifundiários e comerciantes contra os camponeses e a Igreja, gerou, segundo carta do EZLN datada de 1992, a morte de mais de 60 mil pessoas, em sua maioria pobres.

A maioria da população indígena vive em vilarejos situados nos ejidos conquistados no processo de reforma agrária viabilizada pela burguesia mexicana para conter as pressões das massas camponesas, após a Insurreição Revolucionária de Pancho Villa e Emiliano Zapata. Apenas no Estado de Chiapas são 1887 ejidos.

"Era necessário desmilitarizar a vida política mexicana e estabelecer o predomínio da ordem institucional e da administração civil. Era necessário subordinar os militares, para evitar restaurações conservadoras ou caudilhistas.

$\mathrm{O}$ outro tema central eram as chaves populares. A nova ordem implantada deveria reconhecer as conquistas fundamentais dessas forças, a fim de neutralizá-las tanto no presente como no futuro.

Com esse horizonte de preocupações, reuni-se em Querétaro um Congresso Constituinte que, em 5 de fevereiro de 1917. Proclamou uma nova Constituição, na época uma das mais avançadas do mundo.

O artigo 27 dessa Constituição estabelece que as terras pertenciam à Nação Mexicana, e apenas a ela caberia a outorga da posse a particulares, medida de grande importância jurídica. A eliminação do latifúndio e a divisão da terra em pequenas propriedades foram sancionadas, estabelecendo uma extensão máxima segundo as diferentes regiões. Reconhecem também a restituição de terras comunais.

Esse mesmo artigo proibiu a propriedade de terra aos estrangeiros, organizações religiosas e beneficentes, sociedades anônimas, empresas industriais, mineiras, comerciais e bancárias." (ALIMONDA, 1986, p.52-53.)

A implantação de hidroelétricas, usinas extrativas de petróleo, serrarias e a expansão da criação de gado são fatores que têm gerado a expulsão dos camponeses e comunidades indígenas de suas terras. Ao refugiarem-se nas montanhas e na selva acabam vivendo precariamente em uma terra de baixa produtividade agrícola. 
Em 1992 o artigo 27 da Constituição Mexicana, resistente às pressões dos latifundiários até então, que impede que as terras dos ejidos sejam comercializadas, é alterado parcialmente. A alteração revoga a proteção da propriedade coletiva, complicando ainda mais a situação das comunidades indígenas e camponesas que vivem entre as montanhas e a selva no estado de Chiapas.

Após a alteração constitucional os ejidatários, em condições de penúria medieval, passaram a vender suas terras a preços baixíssimos. Uma pesquisa publicada no jornal Reforma, no dia 07 de janeiro de 1994, revela que sessenta e dois por cento $(62 \%)$ da população entendem que o conflito em Chiapas foi provocado por problemas sociais. (FUSER,1995).

O México foi "obrigado" a realizar esta alteração constitucional como condição para sua inclusão no Tratado de Livre Comércio da América Latina, o NAFTA. No discurso do presidente Carlos Salinas de Gortari, o México estaria, dessa forma, ingressando no clube dos países desenvolvidos e, com isso conseguiria acesso às tecnologias desenvolvidas por seus parceiros, geraria empregos e se transformaria em uma nova potência mundial.

\section{¡Ya - basta ! - o levante zapatista}

Em 1993 as comunidades realizaram consulta e, nas assembléias, decidiram pelo ataque armado. O comando militar do EZLN não considerava que houvesse boas condições mateiras e, além disso, acreditavam que os contextos nacional e internacional não eram propícios, com a queda do campo socialista, representado pelo Leste Europeu, e as derrotas das guerrilhas latino-americanas; mas apoiou a decisão das comunidades.

O momento histórico do levante armado chamou a atenção da imprensa e de intelectuais de todo o mundo. "O Exército Zapatista de Liberação Nacional ganhou a atenção do mundo em $1^{\circ}$ de janeiro de 1994" (O EXERCITO....2000). No momento em que o México projetava-se para entrar em um dos grupos que dominariam as relações econômicas mundiais (NAFTA), possibilitando, assim, tornar-se uma 
potência global, surge do meio da selva, na região sudeste do país, uma parcela de sua população tomando o controle de sete municípios do Estado de Chiapas.

"Tomamos sete cidades de Chiapas sem atacar civis, na madrugada de $1^{\circ}$ de janeiro, quando o homem mais poderoso do país e seus cúmplices celebravam a entrada em vigor do Tratado de livre Comércio da América do Norte (NAFTA), que tantos prejuízos traria aos mexicanos. O objetivo era transmitir nossa mensagem. Por isso dizemos que a guerra zapatista é por fazer-se escutar, para obrigar o México primeiro-mundista a ouvir sua população esquecida, seu grito de “'Ya basta!' (Já basta!)” (OTIZ, 1996, p.42).

Em primeiro de janeiro de 1994 o Comitê Clandestino Revolucionário Indígena (CCRI) - Comando Geral do EZLN - lança a Primeira Declaração da Selva Lacandona solicitando a participação do povo mexicano para a instituição de um sistema político livre e democrático no México. Como já foi dito anteriormente, trata-se de uma declaração de guerra contra o sistema de Partido de Estado.

A Declaração convoca a Cruz Vermelha Internacional para proteger a população civil e atesta a sujeitabilidade do grupo às Leis sobre a Guerra da Convenção de Genebra.

O Comando Geral do EZLN relata que está colocando em prática a legalidade do que reza o Artigo 39 da Constituição Mexicana, para que uma ditadura de setenta anos não os mate de fome e não venda sua pátria. Conforme o texto do Artigo 39: "A soberania nacional reside essencialmente e originalmente no povo. Todo poder público emana do povo e se institui em benefício dele. Em qualquer tempo, o povo tem o inalienável direito de alterar ou modificar a forma de seu governo." (GENNARI, 2000b, p.13).

De fato, ficou registrado como características do movimento o projeto de declarar guerra ao NAFTA. Porém, o movimento zapatista não é simplesmente um levante armado contra o Acordo de Livre Comércio e a ideologia neoliberal. Mas a grosso modo é desta forma que o movimento ficou conhecido e, ainda em nossos dias, esta é a principal característica apontada pela imprensa e por alguns intelectuais ao se referirem ao movimento. 
"O que deu à sublevação zapatista este caráter de novidade foi o momento eleito para levá-la a cabo: se deu em um período de refluxo esquerdista mundial, em particular, em um momento em que outros movimentos de guerrilha na América Central deixavam as armas e chegavam a acordos políticos com os neoliberais do poder.(...) A natureza sumamente política e, mais especificamente anti-imperialista do movimento ficou manifesta no momento eleito para a sublevação." (PETRAS; VIEUX, 1998, p.58-59).

O EZLN criou assim uma imagem extremamente forte, esta foi uma das possíveis causas de sua resistência ao longo dos últimos anos conquistando simpatizantes em todo o mundo. A porta de entrada nas discussões políticas mundiais, era tudo o que precisavam. Se não houvesse esta forte representação contra o NAFTA, poderia ter sido confundido com grupos narcotraficantes, ou algo do tipo, através do domínio e manipulação dos aparelhos de imprensa por parte do Presidente mexicano. "Temíamos que nos acusassem de narcoguerrilheiros, de não sermos majoritariamente índios, de sermos estrangeiros ou manipuladores de índios. Foi o que o Governo tentou fazer. Por isso optamos por uma ação que deixasse claras nossas intenções." (ORTIZ, 1996, p.42).

O governo responde ao ataque de $1^{\circ}$ de janeiro com a militarização da Região, prisões, execuções, e até bombardeio em algumas comunidades. Estimulados pelos simpatizantes que o movimento conquistou logo de início no mundo todo, a sociedade civil realiza um protesto no dia 12 de janeiro na cidade do México reunindo dezenas de milhares de pessoas reivindicando uma saída política para o conflito e a suspensão imediata das atividades militares contra o EZLN.

\section{EZLN e sociedade: a mobilização da sociedade civil}

Na Segunda Declaração da Selva Lacandona, de 12 de junho de 1994, o Comitê Clandestino Revolucionário Indígena (CCRI), Comando Geral do EZLN, deposita na sociedade civil a responsabilidade para romper com a cultura da corrupção que impede a justiça e a democracia com um sistema de Partido de Estado. 
Os zapatistas convocam a sociedade civil para assumir um governo de transição política à democracia, para atuar politicamente, assim como o fizera quando exigiu a paralisação do massacre militar que o Exército Mexicano realizava nas regiões da guerrilha, em 12 de janeiro de 1994, quando houve a mobilização de dezenas de milhares de pessoas.

Criticam e "condenam à morte" o sistema de Partido de Estado como condição necessária para a transição rumo à democracia. Colocam a questão nacional como um problema a ser resolvido como condição de desdobramento e resolução do caso em Chiapas. "Não resta dúvida que o governo de Salinas pretende impor-se através da cultura da fraude(...)" (GENNARI, 2000b, p. 18).

A partir da transição para a democracia, liberdade e justiça, pressupõe-se que nascerão outros partidos e organizações coletivas com uma nova cultura e participação política. Os zapatistas não lutam por uma revolução que simplesmente constitua um novo grupo no poder, mas sim por um novo espaço político, livre e democrático.

Nesta Segunda Declaração lançam a proposta para a formação de uma Convenção Nacional Democrática com poderes para estabelecer um governo provisório. Pede-se a deposição do então Presidente Carlos Salinas de Gortari e a elaboração de uma nova Constituição. O EZLN demonstra a visualização de uma realidade política mais ampla e participativa para o México.

A nova Constituição é entendida como referência de uma nova sociedade e não como a petrificação da antiga através de uma nova Constituição. Esta apenas assegura direitos e a possibilidade de se criar novos direitos.

"Claude Lefort em 1987 (apud SILVEIRA, 1997, p.46-47), destaca a eficácia da dimensão simbólica dos direitos do homem como constitutiva da sociedade política. Dimensão que transcende o particularismo dos interesses que buscam afirmar-se a partir de uma legalidade instituída; pois, por cima desta se impõe uma noção de direitos que resulta do entendimento que a sociedade dá a si mesma no que diz respeito ao que seja justo ou injusto. Noção de direitos, portanto, que traz inscrita uma noção de justiça, pela qual se julga a validade e legitimidade das demandas sociais, atribuindo-se ou negando-se direitos a uns e a outros." 
Para o EZLN a população está excluída da participação política. $\mathrm{O}$ povo apenas elege os representantes propostas em um universo político restrito. Procura então demonstrar à sociedade civil seu espaço, através dos fatos, apontando para a necessidade de criar uma nova cultura política, democrática e verdadeiramente participativa.

A política internacional dominante do neoliberalismo e a revolução tecnológica da globalização potencializou a transmissão de informações por toda a parte do planeta, tal conjuntura influencia o estabelecimento de uma nova consciência política mundial. O que acontece no México não é diferente do que acontece em outros países da América latina ou da Europa. A dominação exercida pela ideologia neoliberal atinge, em ritmo muito forte e progressivo todos os cantos do planeta. As pessoas, independentemente das fronteiras territoriais de cada país, estão acompanhando em suas vidas, diariamente, as mudanças dos valores políticos da dominação imperialista transnacional.

"Porque muitas coisas mudaram. O sujeito, o cidadão a quem se dirigem já não é o mesmo. Já não é aquele para quem os políticos julgam falar. E o raciocínio político da esquerda tradicional não está preparado para compreender o momento histórico contemporâneo. A evolução tecnológica, a mutação econômica e a mudança sociológica estão alterando tudo. Atualmente, aqui, ninguém à Esquerda pode dizer o que vai acontecer, o que é preciso fazer, como se deve agir. Nem à Direita. Constatamos que a classe política profissional se afastou radicalmente do seu principal interlocutor, que é a sociedade. Agora, há duas realidades: a dos políticos, falsa, e a da sociedade, real. Se não conseguirmos voltar a fazê-las coincidir, a história virá pedir satisfações. De forma brutal. E isso é válido para qualquer país." (MONTALBÁN, 2000, p.10)

O objetivo zapatista de abrir espaço para a participação da sociedade civil diferencia o grupo de outras guerrilhas tradicionais, mas também não aproxima de grupos reivindicatórios de necessidades específicas, tais como os movimentos pelos direitos dos gays se casarem ou os movimentos ecológicos. A aceitação de idéias diferentes, quaisquer que sejam, desde que oriundas do povo, negando as posturas dogmáticas tradicionalmente conhecidas, e principalmente a ausência 
da ânsia pela tomada do poder, parece ser resultado da forma de contato ocorrida entre o grupo guerrilheiro urbano e as comunidades indígenas.

Apesar do aspecto novo e das peculiaridades regionais do movimento, os zapatistas não deixaram de manter uma postura e atitude política diante dos acontecimentos atuais que potencializam a dominação capitalista e a ideologia neoliberal em todo o mundo.

"Nós nos vemos como sintoma de algo maior que está acontecendo no mundo, onde muitos dizem, ou gostariam de dizer ' $i$ Ya basta!'. Antes não se escutavam, porque o poder mundial construiu um mundo paralelo, fictício, onde se aceita que tudo anda bem, mas não é verdade. Embaixo desse universo virtual existe o belo 'vício' do ser humano, de sempre querer melhorar e mudar, de não conformar-se." (ORTIZ, 1996, p.44)

O EZLN procurou evitar o confronto armado e buscar uma solução pacífica, através da Convenção Nacional Democrática com o intuito de buscar apoio da sociedade civil e de movimentos democráticos de outros países, conforme o estabelecido na Segunda Declaração da Selva Lacandona.

Em janeiro de 1995, o EZLN envia "ao povo mexicano" e "aos povos e governos de todo o mundo" a Terceira Declaração da Selva Lacandona, explicando sua não intervenção, ou não-participação, nas eleições realizadas em 21 de agosto de 1994. Mas não se cala diante da corrupção e fraude eleitoral ocorridas no processo de votação, determinado no texto como crime de Estado. O texto descreve o PRI (Partido Revolucionário Institucional) como braço político do crime organizado e do narcotráfico.

Segundo esta Declaração, o EZLN viu-se forçado a mostrar ao mundo que a apatia voltava a tomar conta da sociedade civil e que as vias eleitorais e o vigente sistema de Partido de Estado não solucionariam a situação em Chiapas. Por consideração a suas convicções políticas que visam uma sociedade democrática, livre e justa, julgaram de seu dever mostrar ao México e ao mundo que não há forma de incorporar os indígenas à nação sem que ocorram mudanças nas esferas política. econômica e social. De forma que por tais razões decidiram romper o 
cerco militar e, no dia 19 de dezembro de 1994 , sem disparar sequer um tiro, tomaram trinta e oito (38) municípios de Chiapas e os declararam territórios rebeldes.(GENNARI, 2000b, p.30)

Os zapatistas determinam a necessidade de uma transformação nacional - contrariando as interpretações que afirmam que o movimento é regionalista - e propõe que a autonomia é a forma mais adequada de respeitar as peculiaridades culturais, políticas e de organização social dos indígenas. Considerando que a autonomia não é sinônimo de separação e sim de integração das populações, que o México dos "primeiromundistas" preferiu esquecer. O conceito de autonomia é inserido pelo movimento como forma de participação, de realização política que permite ao indivíduo uma convivência social digna no sentido de poder ser politicamente livre e igual ao "outro".

"Porque a autonomia não é eliminação pura e simples do discurso do outro, e sim elaboração desse discurso, onde o outro não é material indiferente porém conta para o conteúdo do que ele diz, que uma ação inter-subjetiva é possível e que não está fadada a permanecer inútil ou a violar por sua simples existência o que estabelece como seu princípio" (CASTORIADIS, 1982, p.129).

Pressupõe a noção de sociedade, onde as desigualdades não estão presentes como relacionadas e determinadas exclusivamente pelo "direito à propriedade", mas na individualidade dos sujeitos constituidores de um coletivo mais justo, que possa ser construído a partir da interação participativa e não através da obediência, ou aceitação passiva, ao que é imposto.

Os zapatistas reafirmam sua postura política, que pode ser sintetizada em uma de suas frases mais presentes nos textos e comunicados do grupo: "PARA TODOS TUDO, PARA NÓS NADA". Não podemos entender com isso que o EZLN esteja pretendendo assumir um discurso heróico de revolucionários que se excluem do processo de conquistas em benefício do restante da população do país. Parece tratar-se da inclusão de toda a sociedade, descartando qualquer pretensão de comando deste processo por parte do EZLN ou de qualquer outro grupo político. 
Na realidade, a reflexão que se pode fazer é semelhante à proposta por Castoriadis (1982). Não se trata de exclusão, mas de inclusão, com a liberdade igual a todos os demais indivíduos que constituem a sociedade e, consequentemente. estão inseridos igualmente no mesmo espaço político, “ (...) não podemos desejar a autonomia sem desejá-la para todos e que sua realização só pode conceber-se plenamente como empreitada coletiva." Parece que os zapatistas desejam deixar claro que suas reivindicações envolvem toda a sociedade mexicana, não se tratando de um movimento voltado apenas para seus problemas locais como se fossem isolados do restante da nação. Demonstram ter consciência clara a respeito do espaço público como constituído pela "intersubjetividade" de todos e de cada um.

A Terceira Declaração da Selva Lacandona convoca todos os mexicanos, independente de raça, cor, ideologia política, religião ou opção sexual, que desejam uma nação democrática e o fim do sistema de Partido de Estado, para unirem-se ao Movimento para a Libertação Nacional.

A necessiade de consquistar novos direitos e, além disso, novas instituições, que possam garantir a reavalição constante destes direitos por toda a sociedade, estão presentes nesta Declaração.

O Movimento Zapatista traça sua história, que neste segundo momento é construída a partir da inter-relação com a sociedade civil, em busca de Democracia, Liberdade e Justiça. O movimento não demonstra qualquer anseio de tomar o poder do Estado para sua gerência, como os movimentos sociais tradicionalmente baseados nas "teorias marxistas ortodoxas". A empreitada do movimento parece objetivar a participação política no âmbito das relações sociais da sociedade civil, entendida como o espaço público como um todo, envolvendo todas as esferas componentes da sociedade. $\mathrm{O}$ que os zapatistas buscam parece ser o direito à distinção, e à liberdade de conquista do espaço público que Hannah Arendt (1990, p.96) coloca como "principais vícios e virtudes do homem político".

"É exatamente porque o tirano não aspira a distinguir-se, e se ressente da falta de qualquer paixão por distinção, que ele se compraz em colocar-se acima da companhia de todos os homens; inversamente, é o desejo de distinção que faz os homens amarem o mundo e apreciarem a companhia de seus semelhantes, e os conduz à atividade pública.' 
A incansável busca dos direitos destituídos com a alteração do Artigo 27, a incessante reivindicação pelo direito à autonomia, a forma de relaciona-se internamente sem um líder representante e sim com um Comitê (CCRI) que sempre apregoa estar "mandando obedecendo", a forma de relacionar-se com a sociedade e sua postura diante do Estado, são traços de uma cultura política que não poderíamos classificar, ou rotular, considerando que a mesma propõe-se uma atividade de constante construção nas interações internas e externas do grupo, abrangendo nas discussões o maior número possível de pessoas da sociedade. Parece que os zapatistas, além de uma nova postura política, demonstram trazer também uma nova consciência acerca dos "Direitos do Homem" no sentido colocado por Claude Lefort (1987, p.69):

"Política dos direitos do homem, política democrática, duas maneiras, pois, de responder à mesma exigência: explorar os recursos de liberdade e de criatividade nos quais se abebera uma experiência que acolhe os efeitos da divisão; resistir à tentação de trocar o presente pelo futuro; fazer o esforço ao contrário para ler no presente as linhas da sorte indicadas com a defesa dos direitos adquiridos e a reivindicação dos direitos novos, aprendendo a distingui-los do que é apenas satisfação do interesse."

Os zapatistas demonstram-se dispostos a construir uma nova relação entre os membros da sociedade mexicana, procuram incluir todo o povo mexicano em sua busca por um espaço político construído de forma autônoma e democrática."Nossa luta é pelo respeito ao nosso direito de governar e nos governarmos, e o mau governo impõe à maioria a lei da mimoria." (GENNARI, 2000b, p.36) Com esta perspectiva o EZLN convoca novamente, através da Quarta Declaração da Selva Lacandona de $1^{\circ}$ de janeiro de 1996, a sociedade civil mexicana para formar uma nova instituição política autônoma, a Frente Zapatista de Libertação Nacional. ${ }^{+}$

"A Frente Zapatista de Libertação Nacional nasce hoje e convidamos a participar dela os operários da República, os trabalha-

\footnotetext{
+ No dia 13 de setembro de 1997 foi fundada, na Cidade do México, a Frente Zapatista de Libertação Nacional.
} 
dores do campo e da cidade, os indígenas, os colonos, os professores e estudantes, as mulheres mexicanas, os jovens de todo o país, os artistas e intelectuais honestos, os religiosos coerentes, todos os cidadãos mexicanos que não querem o poder e sim a democracia, a liberdade e a justiça para nós e nossos filhos.

(...) Uma força política que possa organizar as demandas e propostas dos cidadãos para que quem mande, mande obedecendo. Uma força política que possa organizar os problemas coletivos, mesmo sem a intervenção dos partidos políticos e do governo. Não necessitamos pedir permissão para ser livres. A função do governo é prerrogativa da sociedade e é seu direito exercer sua função. Uma força política que lute contra a concentração da riqueza em poucas mãos e contra a centralização do poder. Uma força política cujos integrantes tenham como único privilégio a satisfação do dever cumprido.

(...) Uma força que lute contra o sistema de Partido de Estado. Uma força que lute pela democracia não apenas na hora das eleições. Uma força política que lute por uma nova constituinte e uma nova Constituição.

Chamamos a todos(...); aos que estão de acordo com que se faça uma nova Constituição que incorpore as principais demandas dos mexicanos e garanta o cumprimento do Artigo 39, mediante plebiscito e referendum; aos que não aspiram ou pretendem exercer cargos públicos ou postos de eleição popular; (...)aos que querem deixar de ser espectadores e estão dispostos a não ter remuneração e privilégio algum a não ser participar da reconstrução nacional; aos que querem construir algo novo e bom, para formar a Frente Zapatista de Libertação Nacional."

Nesta Quarta Declaração o Comitê Clandestino Revolucionário Indígena (CCRI) relata que estão trabalhando nos preparativos para o Primeiro Encontro Intercontinental pela Humanidade e contra o Neoliberalismo. O encontro, que ficou conhecido como "Reunião Intergaláctica", foi realizado em julho de 1996 e contou com a presença de cinco mil pessoas de quarenta e dois (42) países.

Como já ficou demonstrado anteriormente, a consciência, a cultura e a postura política do movimento foram formadas pela inter-relação entre o grupo urbano e os indígenas. Provavelmente duas formas distintas de entender a condição política do país, a própria condição de grupos distintos e a perspectiva e interesse de atuação conjunta. Duas formas distintas de devir histórico como propõe Lefort (1990). 
Seria presunção de nossa parte querer determinar exatamente o que os zapatistas estão construindo histórica e culturalmente no México e, porque não dizer, no mundo. O que nos permitimos realizar aqui é uma reflexão, mais para levantar questões, colocando o movimento zapatista como algo novo e contemporâneo, do que para estabelecer um pensamento determinante do que surgiu em Chiapas.

Neste sentido poderíamos concordar que a noção de democracia dos zapatistas condiz com o que Castoriadis coloca repensando a origem da palavra na Grécia que continha o significado de isonomia como "a igualdade da lei para todos" que no contexto de uma sociedade autônoma pressupõe a necessidade de existência de indivíduos também autônomos, livres. Ou seja, liberdade como igualdade na participação política. "A liberdade, a autonomia, implica necessariamente a participação ativa e igualitária em todo o poder social que decide sobre os problemas comuns.(...) Autônomo significa aquele que se dá a lei a si mesmo." (CASTORIADIS, 1983, p.21).

Parece que o que o EZLN vem realizando nada mais é do que seguindo a ótica de Lefort e Castoriadis - uma tentativa de quebrar a submissão entre uma sociedade instituída e uma sociedade instituinte, como busca de uma sociedade mais justa onde as leis podem e devem ser discutidas coletivamente (CASTORIADIS,1983). Diferente de um movimento social que visa a formação de um Estado onde os direitos individuais são extirpados do cidadão em "benefício" dos interesses do todo, a saber, o "corpo político" (LEFORT, 1987, p.44). Ou como coloca Ricardo de J. Silveira (1998, p.73) acerca do Manifesto Comunista de Marx \& Engels: "As opiniões particulares não importam, porque derivam de posições de atores já dadas pelo movimento histórico, e que determinam o que os atores farão, o que só pode ser congruente com o que já é teoricamente sabido."

Pouco antes das eleições presidenciais de 02 de julho de 2.000 , em um texto datado de 19 de junho de 2.000 , o EZLN deixa claro que não participa do processo eleitoral e das lutas partidárias, mas não intervem nos andamentos rotineiros das eleições, tambéminclusive nas seções estabelecidas em zonas zapatistas. Porém deixa claro que sua concepção de democracia vai além da disputa eleitoral: "No ideário zapatista, a democracia é algo que se constrói a partir de baixo e com todos. Inclusive com aqueles 
que têm um pensamento diferente do nosso. A democracia é o exercício do poder por parte das pessoas o tempo todo e em todos os lugares."

Nas eleições presidenciais deste ano venceu e foi eleito o candidato do Partido Ação Nacional (PAN), Vicente Fox Quesada, substituindo o Partido Revolucionário Institucional (PRI) que estava no poder desde 1929, "O mais perto que a oposição havia chagado para desbancar o PRI foi em 1988, quando Cárdenas ganhou as eleições presidenciais, mas os resultados foram manipulados pelo governo, dando vitória ao candidato priista Carlos Salinas de Gortari."(MELLO, 2000).

O Exército Zapatista de Libertação Nacional possui muitos traços que necessitam ser estudados com mais profundidade, a própria relação com a sociedade civil vai muito além, imaginamos, do que pudemos expor neste trabalho. Constitui uma rica fonte de estudos para as Ciências Sociais; no entanto, nossa intenção, como já temos dito anteriormente, é apenas levantar questões sobre esse contemporâneo movimento social que ocorre no México.

\section{Considerações finais}

O Exército Zapatista de Liberação Nacional foi formado em 1983 e constituiu-se a partir das relações estabelecidas entre dois grupos distintos: um grupo urbano, desencantado com as vias políticas institucionalizadas, pela limitação que ofereciam a qualquer mudança. Esse grupo refugia-se na Selva Lacandona com a intenção de iniciar um movimento de guerrilha. E um grupo de camponeses indígenas, com uma cultura distinta da anterior, mas que compartilha da mesma realidade político-econômico-social presente em todo o país e apresentada numa situação de maior miséria e exclusão no estado de Chiapas.

Não podemos afirmar que um grupo sobressaiu-se ou dominou o outro, longe disso, o EZLN constituiu-se mediante uma relação pautada no respeito às diferenças de cada grupo. Essa relação pode ter-se dado pelo fato dessas comunidades indígenas já conviverem com a

sCRI - O CG-EZLN diz sua palavra diante do próximo processo eleitoral nacional (GENNARI. 2000b, p.171). (grifo do autor) 
diversidade nos contatos efetivados entre seus quatro principais grupos étnicos, como também com a própria população camponesa e urbana não-indígena. Mas para afirmar isso seria necessário realizar um estudo voltado especificamente para esta questão, talvez, levando-se em conta os traços político-culturais herdados das civilizações maia e asteca ou um estudo dos conflitos com os colonizadores espanhóis. Enfim, esta seria uma questão para um outro trabalho.

A "noção de direitos" como construção coletiva é uma característica importante do movimento, que deve ser considerada particularmente na relação com a sociedade civil mexicana. O EZLN coloca em questão a legitimidade do Estado constituído sem o anseio de tomar para si o poder de geri-lo. Trata-se de uma visão pluralista, uma visão de respeito à diferença, sem modelo previamente definido. Mas nem por isso poder-se-ia afirmar que o movimento nada tem de marxista, bastando, apenas para apontar esta questão, lembrar que o grupo urbano possui uma formação política basicamente marxista-leninista, a qual não é negada em nenhum momento de sua prática.

A forma como se constituiu o EZLN demonstra a capacidade dos indivíduos do movimento em lidar com as diferenças culturais presentes em sua realidade social de atuação. A pluralidade presente em sua formação também é encontrada na relação do movimento com a sociedade civil mexicana.

É a necessidade de criar um novo espaço político, amplo e participativo, que faz do EZLN um movimento com simpatizantes em todo o mundo. O que querem os zapatistas não é diferente do que quer toda a população excluída do direito de construir suas próprias leis e de poder contestá-las sempre que pensar ser preciso, seja no México seja em qualquer parte do mundo.

No dia primeiro de janeiro de 2001, o EZLN comemorou sete anos de levante. Nesta mesma data o subcomandante Marcos escreve em Correspondência à Senhora Sociedade Civil, Nacional e Internacional, reafirmando as três condições necessárias para o início de uma verdadeira negociação de paz. Reivindicando a retirada total do Exército Mexicano de sete posições militares da zona de conflito, das quais duas já foram desocupadas; a libertação de mais de cem integrantes do EZLN, além dos 17 já libertados; e o reconhecimento dos direitos e da cultura indígenas. 


\section{Referências Bibliográficas}

ALIMONDA, Héctor. A Revolução Mexicana. São Paulo: Ed. Moderna. 1986.

ARENDT.Hannah. Da Revolução. In: A busca da felicidade. São Paulo: Ática, 1991. Cap.3

CASTORIADIS, Cornelius. Teoria e Projeto Revolucionário. In:

A Instituição imaginária da sociedade. Rio de Janeiro: Paz e Terra, 1982. Cap.2.

Introdução: Socialismo e Sociedade Autônoma. In:

Socialismo ou barbárie: o conteúdo do socialismo. São Paulo: Brasiliense. 1983.

FUSER,Igor. México em transe. 2.ed. São Paulo: Scritta, 1996.

O EXÉRCITO Zapatista de Liberação Nacional ganhou a atenção do mundo em $1^{\circ}$ de janeiro de 1994. Folha de São Paulo, 14 maio 2000. p.A17.

GENNARI, Emilio. Chiapas: as comunidades zapatistas reescrevem a história. Campinas, 2000a. Texto digitado.

GENNARI, Emilio (Org.). Terra e Liberdade! O grito de Zapata corre o mundo: Campinas, 2000b. Texto digitado.

LE BOT, Yvon. Il Sogno zapatista. Milão: Ed. Mondadori, 1997. Entrevista com o Subcomandante Marcos.

LEFORT, Claude. Direitos do Homem e Política. A Invenção democrática, os limites do totalitarismo. 2.ed. São Paulo: Brasiliense. 1987. Cap.1.

II Sociedade sem história e historicidade. As

Formas da História. 2.ed. São Paulo: Brasiliense, 1990.

Palavras Do Subcomandante Insurgente Marcos Para A MesaRedonda "Da Cultura Subterrânea à Cultura Da Resistência" No Multiforo Alicia (26-10-1999). In: CULTURA VOZES, $n^{\circ} 2$, março-abril, 2.000.

MELlO, Kátia. Fox Trota. Isto é, n.1606. p.102-105. jul., 2000.

MONTALBÁN, Manuel Vazquez. Chegou a hora da sociedade civil. Caros Amigos. ano 3, n.34, p.10, jan., 2000. Entrevista com o Subcomandante Marcos.

ORTIZ,Pedro. Ya Basta! Atenção, ano 2, n.8, p.40-42, 1996. Entrevista do Subcomandante Marcos

PETRAS, James; VIEUX, Steve. Mitos e realidades da sublevação de Chiapas. Lutas Sociais, n.5, p.58-59, 1998. 
SAHLINS, Marshall. Ilhas de História. Rio de Janeiro: Jorge Zahar, 1990.

SILVEIRA. Ricardo de Jesus. As Associações de moradores e a construção do espaço público: um exercício de cidadania. 1997. Tese (Doutorado em Sociologia) - USP, São Paulo. 1997.

Pensando o Manifesto Comunista do Ponto de vista Político.

Tudo Flui: Revista da ADUEL, v.3, n.1, p.73, jan/jul., 1998.

\title{
Sites consultados:
}

\author{
http://www.EZLN.com \\ http://www.zapatistas.com \\ http://www.jornada.unam.mx \\ http://www.redesind.com.br/ezln/ \\ http://www.processo.com \\ http://www.enlacecivil.org \\ http://www.processosur.com \\ http://spin.com.mx \\ http://www.geocities.com/Vienna/2659/historico.htm \\ http://www.nexos.com.mx \\ http://www.ezln.org
}

\begin{abstract}
The gift work presents a first contact with the Exército Zapatista de Libertação Nacional of the State Mexican of Chiapas. It apprehends genese of the Zapatista Movement, from an analysis of its formation politician-cultural, taking itself in consideration the existences differences in the inside of the group. The analysis also turns toward the economic situation of Chiapas at the moment description of Levante Zapatista. And still, deals with the relation of the EZLN with the society civilian Mexican, to leaving of the declarations of the group and of a quarrel theoretician developed concerning the ideology of exactly.
\end{abstract}

Key-words: social moviments; space politician; rights of the man. 